\title{
DIET OF SHORT-EARED OWL AsIo FLAMMEUS (PONTOPIDDAN, 1763) WINTERING IN ROLLAPADU WILDLIFE SANCTUARY AND ITS VICINITY IN ANDHRA PRADESH, INDIA
}

\author{
Bhargavi Srinivasulu ${ }^{1}$ and C. Srinivasulu ${ }^{2}$ \\ 1,2 Wildlife Biology Section, Department of Zoology, Osmania University, Hyderabad, Andhra Pradesh 500007, India \\ Email: ${ }^{1}$ bharisrini@gmail.com
}

\section{Abstract}

Pellets of Short-eared Owl Asio flammeus wintering in the grasslands of Rollapadu Wildlife Sanctuary and its vicinity in Andhra Pradesh, India were analysed. Birds constituted the major prey followed by mammals and invertebrates both in terms of percentage of occurrence $(82 \%)$ and biomass consumed $(87 \%)$, indicating that the species is an opportunistic feeder, taking prey in proportion to their availability. A total of 13 species contributed to the diet, 276 prey individuals totaling $4,522 \mathrm{~g}$ in biomass were found.

\section{KEYwORDS}

Andhra Pradesh, Asio flammeus, diet, Rollapadu WLS, Shorteared Owl

The Short-eared Owl Asio flammeus (Pontopiddan, 1763) is a winter migrant - seen from September/October to March/ April in the Indian subcontinent (Ali \& Ripley, 2001; Grimmett et al., 1998). Short-eared Owls breed across subarctic and temperate Eurasia and North America, and on the grasslands of South America and some islands including Hawaii, the Galapagos, the Falkland Islands, Cuba, Puerto Rico, Borneo and the Philippines. Eurasian birds winter in the Mediterranean region of Europe, northern Africa, and southern Asia to Malaysia (Holt \& Leasure, 1993). In India it is found practically throughout the country affecting open, undulating grasslands with scattered scrub, sparsely scrubbed hillsides, tall grasslands on the margins of jheels and also in semi desert (Ali \& Ripley, 2001). The food habits of the Shorteared Owl wintering in India has not been studied so far, and according to Ali \& Ripley (2001) the species feeds on field rats and mice, small birds, grasshoppers, locusts, beetles, etc. This paper reports the aspects of diet of Short-eared Owl as determined by pellet analysis found at the roost in Rollapadu Wildlife Sanctuary and its vicinity in Kurnool district, Andhra Pradesh.

In India, dietary studies of owls had been sporadically conducted and studies on commoner species pertain to that of Spotted Owlet Athene brama (Kumar, 1985; Jadhav \& Parasharya, 2003; Ramanujam \& Verzhutskii, 2004), Eagle Owl Bubo bubo benghalensis (Ramanujam, 2000, 2001, 2004, 2006), Barn Owl Tyto alba (Kanakasabai et al., 1998; Neelanarayan et al., 1998; Neelanarayan \& Kanakasabai, 2003) and Collared Scops Owl Otus bakkamoena (Verzhutskii \& Ramanujam, 2002).

\section{Study Area}

Rollapadu Wildlife Sanctuary is located $18 \mathrm{~km}$ southeast of Nandikotkur $\left(15^{\circ} 58^{\prime} \mathrm{N} \& 78^{\circ} 18^{\prime} \mathrm{E}\right)$ town in Kurnool district of Andhra Pradesh. The sanctuary is a grassland habitat surrounded by crop fields and lies between the Nallamala and the Erramala Hills at an altitude of $200 \mathrm{~m}$. The terrain is generally undulating with predominately poor red soil. The region is semi arid with an average annual rainfall of $668 \mathrm{~mm}$ received from both southwest and northeast monsoon. Summer (March to May) peaks at $42^{\circ} \mathrm{C}$ and winter (November to February) is mild at $17^{\circ} \mathrm{C}$. Declared as a protected area in 1982 , the wildlife sanctuary covers an area of $9.37 \mathrm{~km}^{2}$ and consists of grazing and disturbance free grassland enclosures that are surrounded by cattle proof trench-cum-mound boundaries separating them from the surrounding crop fields. The grazed grasslands are characterized by short grass $(<30 \mathrm{~cm}$ high) dominated by Chrysopogon fulvus, Heteropogon contortus and Melanocenchrus jacquemontii. The ungrazed grasslands (enclosures) have tall grass $(>60 \mathrm{~cm}$ high) with good ground cover dominated by Heteropogon contortus, Chrysopogon fulvus, and Eremopogon foveolatus. Sehima nervosum (>100cm high) the climax grassland species of gravely soil of these areas (Dadbadghoa \& Shankarnarayan, 1973), has formed pure stands in patches in some area of the enclosures. Carissa spinarum, Cassia auriculata, Cassia fistula, Phoenix sylvestris and Ziziyphus mauritiana dominate the scrubland that dots the grassland habitat especially near the seasonal streams, fringe of the villages and uncultivated revenue lands. The crop fields, fallow lands and grassland stretches surrounding these protected enclosures are essentially similar in their character and harbour similar floral composition but with some tree elements (Srinivasulu \& Srinivasulu, 2004).

\section{Materials And Methods}

While documenting small mammals in the Kurnool grassland, we gathered strigid (Athene brama and Asio flammeus) pellets to determine the presence and diversity of small mammals. Pellets were gathered from three sites - first site within Rollapadu WLS (where three individuals roosted) and two other sites outside the Sanctuary in Jalakanoor grassland areas (where a total of 5 individuals roosted), during the winters of 2000-2001 and 2001-2002. The owls roosted either on ground in the shade of Phoenix sylvestris or on its lower branches near nullahs at all the sites. The pellets were collected on a weekly basis during the first year and opportunistically during the second year. A slightly modified technique of pellet analysis described by Errington (1930) was followed. The collected pellets were air dried to a constant weight and prior to analysis were soaked in $\mathrm{NaOH}$ solution and sieved through a screen mesh to separate bones. The solution was again subjected to sieving to separate smaller components. All bones and other identifiable parts were separated and used for species identification and quantification. Insects were identified

Manuscript 1550; (C) ZOO; Date of publication 21 August 2007 Received 05 April 2006; Revised received 13 July 2007; Finally accepted 10 August 2007 
Table 1. Diet of Short-eared Owl Asio flammeus wintering in grasslands of Kurnool district, Andhra Pradesh

\begin{tabular}{|c|c|c|c|c|c|c|}
\hline & Species & $\begin{array}{l}\text { Number of pellets } \\
\text { with the species }\end{array}$ & $\begin{array}{l}\text { Total no. of } \\
\text { prey found }\end{array}$ & $\begin{array}{l}\text { Percent frequency } \\
\text { of prey }\end{array}$ & $\begin{array}{l}\text { Approximate wt. } \\
\text { of prey (in g) }\end{array}$ & $\begin{array}{l}\text { Total biomass } \\
\text { contributed(in g) }\end{array}$ \\
\hline & Mammals & & & & & \\
\hline 1. & Soft-furred Metad Millardia meltada & 5 & 7 & 3.08 & 23 & 161 \\
\hline 2. & Mouse Mus sp. & 4 & 15 & 6.60 & 16 & 240 \\
\hline \multirow[t]{2}{*}{3.} & Indian Gerbil Tatera indica & 2 & 4 & 1.76 & 25 & 100 \\
\hline & Birds & & & & & \\
\hline 4. & Oriental Skylark Alauda gulgula & 4 & 11 & 4.84 & 21 & 231 \\
\hline 5. & Indian Robin Saxicoloides fulicata & 3 & 7 & 3.08 & 20 & 140 \\
\hline 6. & Common Stonechat Saxicola torquata & 2 & 4 & 1.76 & 22 & 88 \\
\hline 7. & $\begin{array}{l}\text { Greater Short-Toed Lark } \\
\text { Calandrella brachydactyla }\end{array}$ & 118 & 154 & 67.84 & 20 & 3080 \\
\hline 8. & Pied Bushchat Saxicola caprata & 3 & 5 & 2.20 & 22 & 110 \\
\hline \multirow[t]{2}{*}{9.} & Unidentified passeriformes & 5 & 15 & 6.60 & 20 & 300 \\
\hline & $\begin{array}{l}\text { Reptiles } \\
\text { Unidentified reptiles }\end{array}$ & 2 & 2 & 0.88 & 10 & 20 \\
\hline 10. & Invertebrates & & & & & \\
\hline 11. & Orthoptera & 5 & 27 & 11.89 & 1 & 27 \\
\hline 12. & Coleoptera & 7 & 9 & 3.96 & 1 & 9 \\
\hline \multirow[t]{2}{*}{13.} & Arachnida (Unknown spiders) & 3 & 16 & 7.04 & 1 & 16 \\
\hline & Total & 163 & 276 & & & 4522 \\
\hline
\end{tabular}

Number of preyed species - 13; Maximum number of prey per pellet - 5; Average prey per pellet - 1.79 \pm 0.086 ;

Average meal - 29.32g; Average wt. of prey consumed - $16.38 \mathrm{~g}$

following Mani (1990), birds were identified following Ali \& Ripley (1987) and also by comparing their beak parts, claws and feathers with those in the collection of Natural History Museum of Osmania University, Hyderabad, and rodents were identified basing on their skull structure following Agrawal (2000).

\section{Results and Discussion}

Analysis of 163 pellets of Asio flammeus revealed the presence of 276 prey individuals of 13 prey species (including unidentified elements). Average prey per pellet was found to be $1.79 \pm 0.086$ (Mean \pm SE). Prey totalling a biomass of $4,522 \mathrm{~g}$ was consumed giving an average meal of $29.32 \mathrm{~g}$ (Table 1 ). Birds constituted about $87 \%$ of the biomass and were followed by mammals ( $11.39 \%$ of the biomass consumed), invertebrates (1.18\% of the biomass consumed) and reptiles (0.45\% of the biomass consumed).

Unlike earlier studies that revealed that the Short-eared Owl consumed more rodents, especially microtines (Synder \& Hope, 1938; Terres \& Jameson, 1943; Weller et al., 1955; Clark, 1972, 1975; Colvin \& Spauldin, 1983; Wiebe, 1991; Machniak \& Feldhamer, 1993), the owls at Kurnool grasslands fed more on birds than small mammals (Cahn \& Kemp, 1930).

The diet of the predator is governed by the availability of the prey species. Owls in their natural range have been known to show some fair degree in terms of prey selection, but on wintering grounds or during breeding have been reported to take prey opportunistically, in relation to availability (Clark, 1975; Bertolino et al., 2001). Poor results of rodent trapping exercises in the vicinity of wintering roosts in the present study area indicates that the wintering Short-eared Owl in Kurnool grasslands consistently fed upon prey available.

\section{REFERENCES}

Ali, S. \& S.D. Ripley (1987). The Compact Handbook of the Birds of India and Pakistan together with those of Bangladesh, Nepal, Bhutan and Sri Lanka. Oxford University Press, New Delhi. xliv +737 pp.

Ali, S. \& S.D. Ripley (2001). Handbook of the Birds of India and Pakistan. Vol. 3. Stone Curlews to Owls. IInd Edition. Bombay Natural History Society and Oxford University Press, Mumbai.

Agrawal, V.C. (2000). Taxonomic studies on the Indian Muridae and Hysricidae (Mammalia: Rodentia). Records of the Zoological Survey of India, Miscellaneous Publication, Occasional Paper No. 180: 1-177.

Bertolino, S., E. Ghiberti \& A. Perrone (2001). Feeding ecology of the Long-eared Owl (Asio otus) in northern Italy: Is it a dietary specialist? Canadian Journal of Zoology 79(12): 2192-2198.

Cahn, A. \& J. Kemp (1930). On the food of certain owls in east-central Illinois. Auk 47: 323-328.

Clark, R.J. (1972). Pellets of the Short-eared Owl and marsh hawk compared. Journal of Wildlife Management 36: 962-964.

Clark, R.J. (1975). A field study of Short-eared Owl Asio flammeus (Pontopiddan), in North America. Wildlife Monographs 47: 1-67.

Colvin, B. \& S. Spaulding (1983). Winter foraging behaviour of Shorteared Owl (Asio flammeus) in Ohio. American Midland Naturalist 110: 124128.

Dadbadghoa, P.M. \& K.A. Shankarnarayan (1973). The grass cover of India. Indian Council for Agriculture Research, New Delhi, xii + 713pp. Errington, P.L. (1930). The pellet analysis method of raptor food habit study. Condor 32: 292-296.

Grimmett, R., C. Inskipp \& T. Inskipp (1998). Birds of the Indian Subcontinent. Oxford University Press, New Delhi, 888pp.

Holt, D.W. \& S.M. Leasure (1993). Short-eared Owl (Asio flammeus). In: Poole, A. \& F. Gill (eds.) The birds of North America. No. 62. Academy of national Cience, Philadelphia, Pennsylvania and American Ornithologists' Union, Washington, D.C. 22pp.

Jadhav, A. \& B.M. Parasharya (2003). Some observations on nesting behaviour and food of the Spotted Owlet Athene brama. Zoos' Print Journal 18(8): 1163-1165.

Kanakasabai, R., P. Neelanarayanan \& R. Nagarajan (1998). Quantifying Barn Owl Tyto alba stertens prey frequency and biomass, pp.153-157. In: Dhindsa, M.S, P.S. Rao \& B.M. Parasharya (eds). Birds in Agricultural Ecosystem. Society for Applied Ornithology, Hyderabad.

Kumar, T.S. (1985). The Life History of Spotted Owlet (Athene brama brama Temminck) in Andhra Pradesh. Monograph of the Raptor Research Centre, Hyderabad, 241pp.

Machniak, A. \& G. Feldhamer (1993). Feeding habits of Short-eared 
Owls overwintering in southern Illinois. Transactions of the Illinois State Academy of Science 86(1\&2): 79-82.

Mani, M.S. (1990). General Entomology. Oxford \& Indian Book House Publishing, New Delhi, 912pp

Neelanarayanan, P. \& R. Kanakasabai (2003). Rodent pest management using Barn Owl in Cauvery delta, India. Rodent Research 16: 3-5.

Neelanarayanan, P., R. Nagarajan \& R. Kanakasabai (1998). Studying diet of Barn Owl Tyto alba stertens by pellet analysis, pp.125-131. In: Dhindsa, M.S., P.S. Rao \& B.M. Parasharya (eds.) Birds in Agricultural Ecosystem. Society for Applied Ornithology, Hyderabad.

Ramanujam, M.E. (2000). Food consumption and pellet regurgitation rates in captive Indian Eagle Owl (Bubo bubo bengalensis). Zoos' Print Journal 15(7): 289-291.

Ramanujam, M.E. (2001). A preliminary report on the prey of Eurasian Eagle Owl (Bubo bubo bengalensis) in and around Pondicherry. Zoos' Print Journal 16(5): 487-488.

Ramanujam, M.E. (2004). Methods of analyzing rodent prey of the Indian Eagle Owl Bubo bengalensis (Franklin) in and around Pondicherry, India. Zoos' Print Journal 19(6): 1492-1494

Ramanujam, M.E. (2006). On the prey of Indian Eagle Owl Bubo bengalensis (Franklin, 1831) in and around Pondicherry, southern India. Zoos' Print Journal 21(5): 2231-2240.

Ramanujam, M.E. \& B. Verzhutskii (2004). On the prey of the spotted owlet Athene brama (Temminck) in a forested ravine in Auroville, Pondicherry. Zoos' Print Journal 19(10): 1654-1655.

Snyder, L.L. \& C.E. Hope (1938). A predatory-prey relationship between the Short-eared Owl and the meadow mouse. Wilson Bulletin 45: 110112 .

Srinivasulu, C. \& B. Srinivasulu (2004). Herpetofaunal diversity of Rollapadu Wildlife Sanctuary and its vicinity, Andhra Pradesh, pp. 5260. In: Shankaraiah, K. (ed.), Bioresources, Biotechnology and Bioenterprise, Proceedings of the National Symposium. Department of Zoology, Osmania University, Hyderabad.

Terres, J.K. \& E.W. Jameson Jr. (1943). Plague of mice as food for Short-eared Owl. Wilson Bulletin 55: 131.

Verzhutskii, B. \& M.E. Ramanujam (2002). On the prey of the Collared Scops Owl Otus bakkamoena (Pennant) at Auroville, Pondicherry. Zoos' Print Journal 17(1): 939-940.

Weller, M.W., I.C. Adams Jr. \& B.J. Rose (1955). Winter roosts of marsh hawks and Short-eared Owls in central Missouri. Wilson Bulletin 67: 189-193.

Wiebe, K.L. (1991). Food habits of Short-eared Owls in southwestern British Columbia. Journal of Raptor Research 25(4): 143-145.

\section{Acknowledgments}

We thank the Head, Department of Zoology, Osmania University for facilities; Chief Wildlife Warden and Andhra Pradesh Forest Department for research and collection permits; Staff of Rollapadu Wildlife Sanctuary for logistics and field support. We acknowledge individual Research Grants by Council for Scientific and Industrial Research, New Delhi.

\section{Salim Ali Centre for Ornithology and Natural} History (SACON)

(An autonomous centre aided by the Ministry of Environment and Forests, Govt. of India)

Invites application for the following positions in the short term "Rajahmundry GIS Project"

\section{Remote Sensing Analyst}

Age: 35 years as on 1.08.2007

Educational qualifications: M.Sc. in any branch of Science, experience in Image processing of Satellite data / GIS

Essential Experience: one or two years in Image processing and GIS

\section{Research Fellow}

Age: 28 years as on 1.08 .2007 (relaxable up to 30 years)

Essential qualification: M.Sc. in any branch of Science, experience in Image processing of Satellite data / GIS Essential Experience: one or two years in field work

\section{Research Fellow}

Age: 28 years as on 1.08.2007 (relaxable up to 30 years)

Essential qualification: M.Sc. in Zoology, Ornithology environmental Sciences experience in field work related to biodiversity

Essential Experience: one or two years in field work

\section{Note:}

1. Duration of the project is for a period of six months. Salary is commensurate with qualifications and, work experience.

2. Application on plain paper with complete bio-data in the following format should reach the Director, Salim Ali Centre for Ornithology and Natural History, Anaikatty Post, Coimbatore - 641 108, Tamil Nadu within 15 days of publication of this advertisement: (1) Name, (2) Age as on 1.08.2007, (3) Permanent address, (4) Present address, (5) details of prescribed qualifications (with grades) (6) other qualifications, if any, with grade obtained, (7) total years of experience in the concerned field, (8) positions held with details of pay and responsibilities, (9) present position with salary scale and responsibilities, (10) any other relevant information. Applications not received in the above format are liable to be rejected.

3. SACON will decide the cut off point for calling the candidates for interview based on the academic qualifications, experience and age.

4. Only those who are highly motivated, creative and committed to the cause of nature conservation and prepared to put in strenuous work need apply.

5. Application should be accompanied by certified copies of documents in support of the qualifications and experience claimed. 